\title{
Criminological Aspects of Organized Crime in Albania
}

\section{Jonida Hyka Skëndaj, Phd candidate}

\author{
"Albanian University", Department of Legal Sciences, Tirana, Albania \\ Email:jona2006jus@yahoo.com
}

Doi:10.5901/ajis.2014.v3n3p478

\begin{abstract}
The purpose of this paper is to bring an overview of criminological aspects of organized crime in Albania, provide key characteristics, trends, an analysis of the most prevalent activities of Albanian criminal groups, statistical data for the period 2002-2009 and preventive measures of organized crime. Organized crime is a form of manifestation of criminality and perhaps his particular form. It is a phenomenon that conveys haw fear and wonderment for the mode of functioning and in the same time evokes attraction for mysteries and special way of understanding. Finally, organized crime is an international crime and global concern where detection and combating organized crime requires cooperation and joint operations between countries based on strong penal policies which enable the detection, investigation, proceeding, punishement of its various forms. Specifically bodies such as the police, prosecution and courts of a country should coordinate work with neighboring or regional bodies such as a rapid exchange of information in order to provide data on criminal groups, their activities, modes of action and tools that they use for their hitting.
\end{abstract}

Keywords: Organised crime, albanian criminal groups, preventive measures, statistical data

\section{Introduction}

Around the world is shocked by the events of the twentieth century, accompanied by an increase in crime. Criminologist, sociologist, psychologist establish that the measures taken for the prevention of crime and its forms are insufficient. Although organized crime is a complex phenomenon, concern around the world for a long time in various countries, for it have existed various concepts and definitions.

The term "organized crime" is used in 1896, on the annual report of the Society for the Crime Prevention, in New York. In this report, this term was used for acts of prostitution and gambling, protected by public official (Fijnuat, C \& Paoli, L, 2004). For the first time the concept of "organized crime" was sanctioned by the law, specifically in federal statutes of America, in 1968, where with organized crime understood illegal activities of members of well-organized, and a union disciplined and committed in support services and illegal trade, including: gambling, narcotics, threats at work and other criminal activities of members of these groups (Adamoli, S; Di Nikola, A \& Savona, E, 1998). Then, criminal codes of different countries gave the definition of the concept of "organized crime". Thus, the Canadian Criminal Code of 1989 defined the meaning of organized crime, including, as this form of crime, 24 types of crimes. Italian Criminal Code (Article 416) has defined organized crime as a crime of type mafioso (Adamoli, S; Di Nikola, A \& Savona, E, 1998). Despite the size that got organized crime in the albanian reality, for a long time albanian legislation does not give a definition of the term "organized crime". The first attempts to give a definition, are made in different studies and scientific articles to the albanian scholars. In early 1994, the professor Ismet Elezi (Elezi, I, 1994) defines organized crime as the highest level of professional crime organization and the creation of groups and different organized gangs who collaborate on a regular basis for committing offenses. Another albanian researcher, Zamir Poda (Poda, Z, 1998), wanting to give a definition of organized crime, stresses: to talk to, first of all need to talk about the mafia, as a criminal organization.

By law no. 8920, dated 11.07.2002, Albanian Parliament ratified the United Nations Convention "Against Transnational Organized Crime" and two extra protocols: 1. protocol "against of immigrants trafficking by land, air and sea" and 2. protocol "for the prevention, obstruction and punishment of trafficking in persons, especially women and children. Ratification of this convention makes it an integral part of the albanian legislation and article 2 of her, has solved the problem of the notion of organized crime, in Albania (Convention of the UNO, 1953).

\section{Methodology}

To highlight the criminological aspects of organized crime in Albania means to characterize it in all aspects. Realization of this goal can be done on the basis of studies conducted about the phenomenon by aboriginal and foreign researcher $(\mathrm{V}$, Hysi; Friman, H \& Reich, S, 2007), statistical data of all bodies involved in combating and preventing it. 
In this paper will be presented the most prevalent activities of albanian criminal groups, based on statistical data and reports of various international institutions (HEUNI, UNICRI, UNDCP), the Council of Europe, research centers and independent scientific (Council of Europe, 2004). Periodic studies or various reports of organized crime, also publish institutions charged with the prevention and investigation of crimes such as the police, the prosecution, the court, Ministry of Justice and the Ministry of Public Order (IOM \& Ministry of Public Order, 2001).

\section{Analysis}

In this paper will be an analysis of the most common activities of albanian criminal groups, based on different measurement models, as in the international study of crime victims (UNICRI, 2001), in reports of various international institutions (HEUNI, UNICRI, UNDCP), in the official records of the Council of Ministers (Council of Ministers, 2001), in reports of the Ministry of Public Order (Ministry of Public Order, 2002) as well as interviews conducted by local and international organizations, whose mission is to provide support to victims of trafficking (IOM \& ICMC, 2001).

Another interesting study in the field of measuring damages that causes organized crime is offered by Savona (Savona, E, 2009) in the framework of a project that aims better recognition of organized crime. Among a detailed analysis of the literature that exists in this field, he identifies some difficulties in measuring the damage that causes organized crime, as: measuring the cost of crime, the definition of indirect costs, the costs of society and the difficulties of data collection. The purpose of these methods is to distil data systematically about the number of people who are most vulnerable to being trafficked, the pressures that may be made to individuals to support to support them in various stages of criminal activity and full evaluation of crimes reported and unreported otherwise called dark figure of crime.

\section{Result of the Study}

Results of the study of organized crime are structured in three categories which are: Trafficking of women, child trafficking and drug trafficking. In these results will reflect the number of officially registered cases.

\subsection{First category: Trafficking of women}

Illegal trafficking of women is one of the most prevalent forms over these years in Albania. Albanian criminal groups to draw greater profits, were connected to the network traffic in neighboring countries. Cooperation with the latter was necessary because the realization of traffic require the fulfillment of certain duties and involvement of people who have certain role in such trafficking as: finding women, their transportation, creation of facilities for transportation, visas, false passports, finding labor market, communication with authors etc.

The study of cases detected in the country and evidence of the girls returned and questioned (IOM \& ICMC, 2002) show that criminal groups have used fraud, promise of marriage, work or a better life, forcible coercion or abduction for the purpose of prostitution in different countries of Europe, mainly in Italy, Greece. For the number of albanian females, victims of this traffic, has different data. Currently according to the albanian government (Council of Ministers, 2001), in different european countries is thought that there are 8,000 albanian women wich utilized with obligation, while the number of those who practice prostitution willingly or in secret, not known exactly.

Disturbing phenomenon after 1996 became traffic of foreign women through the territory of Albania (IOM \& ICMC, 2001). Their trafficking is made from Greece to Albania, with the destination Italy. To realize traffic, criminal groups have cooperated with criminal groups in countries through which pass. For example, trafficking of moldovan and romanian girls is done by passing them to the limit of their countries, in Serbia, in Montenegro, to arrive later in Albania, with the destination Italy or other countries (Sadikaj, B, 2002). Official data reflect a part of the phenomenon. The number of officially registered cases is scarce, but far less is the number of persons convicted of trafficking for prostitution purposes. (IOM \& Ministry of Public Order, 2001)

Table 1. Issues and persons convicted of trafficking for prostitution

\begin{tabular}{|l|c|c|c|c|c|c|c|}
\hline Years & 2002 & 2003 & 2004 & 2005 & 2006 & 2007 & 2008 \\
\hline Issues & 0 & 14 & 4 & 64 & 17 & 7 & 12 \\
\hline Persons convicted & 0 & 26 & 27 & 73 & 23 & 10 & 15 \\
\hline
\end{tabular}

Albanian criminal groups have been very violent towards victims. During 2000, 168 prostitutes were reported killed by 
their tutors, the majority of wich were albanian and nigerian origin. (UNICRI, 2001).

\subsection{Second category. Trafficking of children}

Besides women, victims of trafficking have been children. Data on the number of children trafficked by criminal groups are not accurate. According to official statistics, there are about 4,000 migrant minors unaccompanied by parents (Council of Ministers, 2001). Only in Thessaloniki are about 1000 children with color (Sadikaj, B, 2002). During 2001, there were 11 minor girls rescued from trafficking (Renton, D, 2001). Within 8 years are missing and 1,000 albanian children and throughout Greece thought that utilized 3000 minors (Bregu, M, 1999).

Table 2. Issues and persons convicted of children trafficking

\begin{tabular}{|l|c|c|c|c|c|c|c|}
\hline Years & 2002 & 2003 & 2004 & 2005 & 2006 & 2007 & 2008 \\
\hline Issues & 0 & 4 & 5 & 5 & 3 & 2 & 5 \\
\hline Persons convicted & 0 & 8 & 14 & 3 & 6 & 2 & 3 \\
\hline
\end{tabular}

\subsection{Third category. Trafficking of drugs}

The geographical position of our country favors drug cultivation and its traffic from east to west. In most cases, Albania is between this traffic. Cultivation, trafficking and the use of drugs has become a problem for the albanian government. Initially, drugs was cultivated in southern and central part of the country, but soon territories planted with cannabis were spread in most of the country. In addition to cultivation of cannabis, Albania is a transit country in the drug traffic of other types from the east to the west.

The amount of drugs trafficked from Albania is considerable. Albanian criminal groups and international groups have perfected its methods of transportation. According to statistics from the italian authorities, the amount of drugs coming from Albania and seized during the period 2004 - 2009 is as follow. (State Police, 2009).

\begin{tabular}{|l|c|c|c|}
\hline \multicolumn{1}{|c|}{ Type } & 2004 & 2005 & 2006 \\
\hline Heroin & $1085 \mathrm{~kg} \mathrm{330} \mathrm{gr}$ & $392 \mathrm{~kg} \mathrm{604} \mathrm{gr}$ & $379 \mathrm{~kg} 162 \mathrm{gr}$ \\
\hline Cocaine & $3 \mathrm{~kg} \mathrm{289} \mathrm{gr}$ & $2 \mathrm{~kg} 130 \mathrm{gr}$ & 0 \\
\hline Hashash & 0 & 0 & $30 \mathrm{~kg} 800 \mathrm{gr}$ \\
\hline Marijuana & $801 \mathrm{~kg} 300 \mathrm{gr}$ & $808 \mathrm{~kg} 322 \mathrm{gr}$ & $3043 \mathrm{~kg} 25 \mathrm{gr}$ \\
\hline
\end{tabular}

\begin{tabular}{|l|c|c|c|}
\hline \multicolumn{1}{|c|}{ Type } & 2007 & 2008 & 2009 \\
\hline Heroin & $173 \mathrm{~kg} 568 \mathrm{gr}$ & $62 \mathrm{~kg} 479 \mathrm{gr}$ & $39 \mathrm{~kg} \mathrm{560} \mathrm{gr}$ \\
\hline Cocaine & $13 \mathrm{~kg} 844 \mathrm{gr}$ & $3 \mathrm{~kg} 880 \mathrm{gr}$ & 0 \\
\hline Hashash & 0 & 0 & 0 \\
\hline Marijuana & $456 \mathrm{~kg} 517 \mathrm{gr}$ & $4 \mathrm{~kg}$ & $1420 \mathrm{~kg} \mathrm{233 \textrm {gr }}$ \\
\hline
\end{tabular}

The number of cases prosecuted in this field is increasing from year to year. For a researcher it is difficult to determine whether this increase in registered cases is the result of increasing the effectiveness of police work or that drug trafficking, after the collapse of human trafficking, has become the most preferred and most profitable of Albanian criminal groups. Annual Statistics of the Ministry of Justice show that the number of criminal cases adjudicated and the number of convicted persons is variable (Ministry of Justice, 2002-2008)

Table 3. Issues and convicted persons for drug trafficking

\begin{tabular}{|l|c|c|c|c|c|c|c|}
\hline Years & 2002 & 2003 & 2004 & 2005 & 2006 & 2007 & 2008 \\
\hline Issues & 12 & 37 & 68 & 25 & 23 & 41 & 28 \\
\hline Person convicted & 7 & 41 & 36 & 34 & 45 & 69 & 46 \\
\hline
\end{tabular}

\section{Discussion}

Numerous discussions about the structure of albanian criminal groups involved in organized crime in Albania or in places where they exercise criminal activities. In general, albanian criminal groups prefer to operate alone, but in activities such 
as human trafficking , drug trafficking, their cooperation with criminal groups in neighboring countries is necessary.

Cases of drug trafficking detected and investigated show that albanian criminal groups have links with groups or people of other countries, such as Italy, Bulgaria, and connections go even further, as America, Holland, England etc (Poda, Z, 2009). In the context of economic globalization, criminal groups and their activities are internationalized, what has dictated the need for them to be able to recognize different markets and change their organization structures (Adamoli, S; Di Nikola, A \& Savona, E, 1998).

Instead of hierarchical structures and centralized, are developing decentralized structures, with few procedures and built on the basis of understanding and alliances between criminal groups. Thanks to the development of means of communication and his speed, are developing new forms of crime, among which we can mention: computer crimes, crimes in the field of environmental, arms trafficking etc. According to studies conducted, criminal groups, enter into alliances with the governments of various countries in order to reduce risks in the countries where they operate (Adamoli, S; Di Nikola, A \& Savona, E, 1998).

\section{Conclusions}

In this work are evidenced most widespread forms of organized crime but what should take great advantage is prevention. The growth of organized crime and professionalism, as well as its internationalization have made that prevention to be very important. Unlike the banal crime prevention, prevention of organized crime requires numerous legal measures, specific detection techniques and investigation of his.

To achieve this aim, it is necessary strengthening of cooperation with the bodies of our state and other states as well as with specialized bodies, drafting of new strategies for the rehabilitation of victims of trafficking by the albanian state. Victims of organized crime are numerous, consenquently, their protection is the requirement of time. In conclusion I would recommend to be made efficiently by the albanian legislation, all the recommendations of Universal Organizations, as Organization of the United Nationst and regional organizations as the Council of Europe and the European Union for the strict implementation of directives which hit organized crime and their illegal activities.

\section{References}

Adamoli, S; Di Nikola, A \& Savona, E. (1998). Organized Crime around the World, HEUNI, Helsinki, 5-6.

Adamoli, S; Di Nikola, A \& Savona, E. (1998). Organized Crime around the World, HEUNI, Helsinki, 4.

Adamoli, S; Di Nikola, A \& Savona, E. (1998). Organized Crime around the World, HEUNI, Helsinki, 11.

Adamoli, S; Di Nikola, A \& Savona, E. (1998). Organized Crime around the World, HEUNI, Helsinki, 13.

Bregu, M. (1999). The fight against organized crime, Tirana, 39.

Convention of the United Nations Organisation. (1953). "On transnational organized crime", 1953, published in summary legal acts to justice, Tirana, 2000.

Council of Europe. (2004). Combating organized crime, edition of the Council of Europe Strasbourg, 537-562.

Council of Ministers. (2001). The national strategy for the fight against human trafficking, State Police report, Tirana, 3-14.

Council of Ministers. (2001). The national strategy for the fight against human trafficking, State Police report, Tirana,13.

Council of Ministers. (2001). The national strategy for the fight against human trafficking, State Police report, Tirana, 10.

Elezi, I. (1994). For criminology, lectures, Tirana, 72.

Fijnuat, C \& Paoli, L. (2004). Organized Crime in Europe, Concepts, Patterns and Control Policies in European Union and Beyond, "Springer", Netherlands, 23.

Poda, Z. (1998). Organised crime, ShBLU, Tirana, 5.

Poda, Z. (2009). The transnational organized crime. Violence and power system, Morava, Tirana, 14.

Hysi, V ; Friman, H\& Reich, S. (2007). Human Trafficking and democratic transition in Albania, Pittsburgh University, Pittsburgh , 96-119.

IOM \& Ministry of Public Order. (2001). "Workshop on operational improvements in combating illegal migration, trafficking and smuggling of migrants in Albania", Tirana, 4-13.

IOM \& Ministry of Public Order. (2001). "Workshop on operational improvements in combating illegal migration, trafficking and smuggling of migrants in Albania", Tirana, 4.

IOM \& ICMC. (2001). Research report on the third country national trafficking victims in Albania, Tirana.

IOM \& ICMC. (2002). Research report on the third country national trafficking victims in Albania (January-December 2001), Tirana. 4-12.

IOM \& ICMC. (2001). Research report on the third country national trafficking victims in Albania, Tirana, 8.

IOM \& Ministry of Public Order. (2001). "Workshop on operational improvements in combating illegal migration, trafficking and smuggling of migrants in Albania", Tirana, 4.

Ministry of Public Order. (2002). Report of the liaison officer of the Italian Interforce Police Mission in Albania, 8. This report is also available at http:// www.mpo.gov.al/mpo/29 july \%20 statistics-clandestine.htm.

Ministry of Justice. (2002-2008). Statistical Yearbook of the period 2002-2008, Tirana. 
Renton, D. ( 2001). Child trafficking in Albania, report, "Save of Children", Tirana, 10.

Savona, E. (2009). A Methodology f or measuring the harm caused by organized crime, 5(1), New York, 69-88.

Sadikaj, B. (2002). The state of organized crime in Albania, Kosovo, Montenegro, Macedonia, and problems related to it, summary speeches, Tirana, 110.

Sadikaj, B. (2002). The state of organized crime in Albania, Kosovo, Montenegro, Macedonia, and problems related to it, summary speeches, Tirana, 90.

State Police. (2009). For the activity of the State Police during 2009, Tirana.

UNICRI. (2001). International Crime (Victim) Survey in Albania, unpublished in albanian.

UNICRI. (2001). International Crime (Victim) Survey in Albania 2000, 16. 